\title{
Has The Business Cycle Been Dampened? The Case Of Canada, Sweden And The United States
}

Bakhtiar Moazzami, Lakehead University, Canada

Bahram Dadgostar, Lakehead University, Canada

\begin{abstract}
Have postwar stabilization policies reduced economic fluctuations compared to earlier periods? Using output data for Canada, Sweden and the United States for the period 1929-2005 and three different de-trending procedures, we found that postwar economic policies have been successful in reducing business cycle volatility. We also found that fluctuations in real output have been significantly dampened during the post-Bretton Woods era compared to earlier periods.
\end{abstract}

\section{INTRODUCTION}

$\mathrm{t}$ is generally believed that post-World War II stabilization policies have played an important role in
reducing economic fluctuations compared to earlier periods. There are many hypotheses on the cause of
moderation in the cyclical behavior of economies over time (Zarnowitz 1992), some of which remain
controversial. The most widely accepted hypothesis is that institutional changes in the economy since the pre-
depression period, such as the rise of fiscal automatic stabilizers (i.e., unemployment insurance payments), financial
reforms such as insurance on bank deposits and private stabilizing agents such as private pension plans have reduced
cyclical volatility. An alternative hypothesis is that structural changes in the economy have resulted in stabilization.

In her study of business cycles in the United Sates, Romer (1986, 1989, 1991) compared volatility estimates using the newly constructed prewar GNP estimates, the first-revised Kuznet's prewar estimates (revised by Gallman (1966), and Kendrick (1961)), postwar commerce GNP and the commodity output series. The results indicated much less stabilization and a much smaller decline in the severity of business cycles between the prewar and postwar eras than the conventional belief. The traditional Kuznet's series, even with the Gallman and Kendrick revisions, is excessively volatile.

Sheffrin (1988) examined whether economic fluctuations, as measured by output, have been dampened in six European countries. He found no significant reduction in these countries except for Sweden in the post-World War II period. He attributes the reduction of volatility in Sweden to their post war stabilization policies. More recently, Bergman and Jonung (1993) re-examined whether economic fluctuations in Sweden and the United States have indeed been dampened in the postwar period. They found that economic fluctuations in Sweden and in the United States have not been significantly dampened in the post-World war period.

In general, the degree of reduction in volatility is debatable based on specific issues of data and the methodology used. The objective of this paper is to use consistent data series and various de-trending procedures to re-examine whether economic fluctuations have been dampened in Canada, Sweden and the United States in the post-World War II period. The main difference between the present study and the existing studies is that this study covers the period of 1990s when central banks were successful in reducing inflationary pressures and interest rates in all three countries. Stabilization policies during the 1990's resulted in one of the longest uninterrupted economic expansions in these countries. In addition, our data series exclude the pre-World War I period for which consistent data are not generally available. Finally, we employ various de-trending methods to examine the sensitivity of our results to the choice of methodology used. 


\section{DATA AND METHODOLOGY}

To reduce the effect of measurement errors in the data, we concentrate on the post-World war One period for which consistent data are available for all three countries. For the United States and Sweden, we use real gross domestic product (GDP) from 1929 to 2005. Data for Sweden is from Statistics Sweden and International Financial Statistics. For the U.S., we used Gordon's historical data for 1929-48 chained to International Financial Statistics from 1949 onwards. While Romer suggested that there were errors in measurement of historical data for the United States, Altman (1992) suggested measurement errors in historical real gross national product (GNP) series for Canada. Altman revised Urquhart's (1986) original estimates of historical real GNP because errors arose from deflating them with a cost of living index. The components of the cost of living index are different from the components of nominal GNP. Altman used Urquhart's nominal GNP estimates and deflated them to real terms using a variety of sector-specific price indices (built largely on price indexes). The new real GNP estimates are different from Urquart's series and would therefore provides a unique opportunity to examine cyclical volatility in Canada using the newly improved estimates of the real GNP.

In order to analyze cyclical volatility levels, the data were subdivided into three periods:

1929 to 1947: $\quad$ the depression and war era.

1948 to 1971: $\quad$ the Bretton Woods or fixed exchange rate period.

1972 to 2005: the floating exchange rate period.

We define business cycles as fluctuations with an average periodicity of 5 to 8 years. Volatility is measured by standard deviations in trend-adjusted data. Therefore, the choice of a method of adjustment for trend is of central importance. Nelson and Kang (1981) show that spurious periodicity in the cyclical component could arise from inappropriate ways of trend adjustment. Canova (1993) examined the properties of the cyclical component computed using different de-trending methods. He finds that the properties of the cyclical component differ considerably across different methods and concludes that it is important to check the results by using several methods of trendadjustment. Following Canova's suggestion, we employ three de-trending procedures:

First, we use the first difference of logarithms of the series. Real business cycle theory suggests aggregate annual time series are made up of three components, a trend component (g), a cyclical component (c) and an error (noise) component (e):

$Y_{t}=g_{t}+c_{t}+e_{t}$ for $t=1, \ldots, T$

In order to analyze business cycles, the cyclical component must be isolated of the series. The first differencing of logarithms approach is a general method to approximate a cyclical component from the series at hand. It assumes that the series is made up of a constant linear time trend (g) and a cyclical component (c). After first differencing, the unit root is removed and the series (y) becomes stationary such that a cyclical component is left behind for analysis. This method is used by Romer $(1986,1989,1991)$ and Sheffrin (1988) among others.

Second, we decomposed the series according to the Hodrick-Prescott (1997) filter. The Hodrick-Prescott filter divides a time series, $\mathrm{y}_{\mathrm{t}}$, into a growth component (g) and a cyclical component (c):

$\mathrm{Y}_{\mathrm{t}}=\mathrm{g}_{\mathrm{t}}+\mathrm{c}_{\mathrm{t}} \quad$ for all $\mathrm{t}=1, \ldots, \mathrm{T}$

The sum of the squared second differences of $g_{t}$ measures the smoothness of the path of $g_{t}$. The $c_{t}$ are deviations from $g_{\text {t }}$. Assuming that over the long-term the mean of the cyclical component is near zero, the decomposition can be formulated as the programming problem:

$\operatorname{Max} \sum\left(\mathrm{y}_{\mathrm{t}}-\mathrm{g}_{\mathrm{t}}\right)^{2}+\lambda \sum\left[\left(\mathrm{g}_{\mathrm{t}+1}-\mathrm{g}_{\mathrm{t}}\right)-\left(\mathrm{g}_{\mathrm{t}}-\mathrm{g}_{\mathrm{t}-1}\right)\right]^{2}$ 
Where $\lambda$ is the smoothness parameter. The larger the value of $\lambda$ the smoother is the solution series. As $\lambda$ approaches infinity, the solution to (3) is the least square fit of a linear time trend model. Following Hodrick and Prescott (1989), we set $\lambda$ equal to $100 .{ }^{1}$ This corresponds to a 5 percent cyclical component (a 5 percent deviation from trend) and one-half percentage change in the growth rate per year.

Third, we used the band pass filter suggested by Baxter and King (1995). Assuming business cycles are characterized by fluctuations in data that persist for periods of six through 32 quarters (suggested by the NBER), Baxter and King developed an optimal band pass procedure that isolates the specific frequencies of the cyclical components through applying a symmetric moving average with k-1 weighted leads and lags to the data series. ${ }^{2}$ This filter removes a low frequency (slow moving) trend variation and smoothes higher frequency irregular variations, while retaining the major features of the business cycle on a specified frequency band. In order to approximate NBER's definition of the business cycle using annual data, the frequency band was approximated to occur between two and eight years. ${ }^{3}$

\section{ESTIMATION PROCEDURE AND RESULTS}

Descriptive statistics on variances and standard deviations of the logarithms for each de-trended series are traditional measurements of volatility. As a general measurement of annual movements in a series, the variance captures both the choppiness and amplitude of short-run variations. The ratios of variances between two periods provide an initial view on changes in the volatility of a series over time. Sheffrin (1988) used the variance ratios to test whether the variances have changed using an F-distribution. However, this method cannot be used if the series under examination are serially autocorrelated. Our preliminary examination revealed that all series used in this study exhibit autocorrelation. To circumvent this problem, Bergman and Jonung (1993) used dummy variables to test for the presence of a break in the amplitude of the variances between two periods. They regressed the squared deviations from the sub-period means on two dummies for the sub-periods. They then tested the equality between the coefficients on the dummy variables using a chi-squared test. In this study, we follow the approach suggested by Romer (1989). Viewing the variances as the mean of the squared differences of a given series from the mean, Romer used the standard test for the differences in two means using serial correlation-robust variances. Following the procedure developed by Newey and West (1987), Romer calculated the standard error of the mean using the following formula:

$\mathrm{Se}=\left(\mathrm{R}_{0}+2 \sum \mathrm{w}_{\mathrm{k}} \mathrm{R}_{\mathrm{k}}\right)^{(1 / 2)}$

Where $R_{k}$ is the kth autocovariance of the series (divided by the sample size) and $W_{k}=1-(k /(J+1))$. The standard error calculated in (4) is consistent in the presence of serial correlation and heteroskedasticity. ${ }^{4}$ Using (4), the test of changing variances between two periods can be conducted using the following statistic:

Test-statistic $=(\operatorname{Var}(\mathrm{I})-\operatorname{Var}(\mathrm{II})) /\left(\mathrm{Se}^{2}(\mathrm{I})+\mathrm{Se}^{2}(\mathrm{II})\right)^{1 / 2}$

This statistic has a standard normal distribution in large samples. The volatility measured by variance ratios and the associated test statistics are presented in Table 1 for the three methods of trend-adjustment. The first two columns report the variance ratios. Column (3) and (4) present the test statistics for the null hypothesis that the variance is equal across the two different sub-periods.

\footnotetext{
${ }^{1}$ In (3), the cyclical component (the business cycle) is defined as percentage deviations from trend, which is different from the business cycle according to the first difference filter which is log growth rates.

${ }^{2}$ Symmetric moving averages with weights that sum to zero result in stationary series that contain quadratic deterministic trends.

${ }^{3}$ De-trending procedures were done using RATS econometric software.

${ }^{4}$ See also Wooldridge (1989), Davidson and MacKinnon (1993). The Newey -West procedure is implemented by the econometrics program Eviews.
} 
Table 1

Variance Ratios and Tests for Dampening of Business Cycles

\begin{tabular}{|c|c|c|c|c|}
\hline Canada & $\begin{array}{c}\text { Volatility Ratio } \\
(1929-47 / 1948-71) \\
\end{array}$ & \begin{tabular}{|c|c|} 
Volatility Ratio \\
$(1948-71 / 1972-2000)$ \\
\end{tabular} & Test Statistics & Test Statistics \\
\hline First Difference of Logarithms & 1.90 & 1.46 & 3.56 & 2.12 \\
\hline Hodrick-Prescott & 2.56 & 1.98 & 3.23 & 2.98 \\
\hline Band Pass & 2.78 & 2.01 & 2.87 & 2.12 \\
\hline \multicolumn{5}{|l|}{ Sweden } \\
\hline First Difference of Logarithms & 1.53 & 1.19 & 2.23 & 1.89 \\
\hline Hodrick-Prescott & 1.97 & 1.45 & 2.87 & 1.94 \\
\hline Band Pass & 1.99 & 2.12 & 2.57 & 3.12 \\
\hline \multicolumn{5}{|l|}{ United States } \\
\hline First Difference of Logarithms & 1.68 & 1.21 & 2.45 & 1.86 \\
\hline Hodrick-Prescott & 2.26 & 1.65 & 3.12 & 2.11 \\
\hline Band Pass & 2.87 & 1.95 & 3.56 & 3.01 \\
\hline
\end{tabular}

All test statistics are significant at the $95 \%$ confidence level suggesting that there has been a significant reduction in volatility in the postwar period. In other words, business cycle fluctuations have been significantly dampened in the postwar era. Table 1 also shows that the volatility in the post-Bretton Woods period (a period with flexible exchange rates) has been significantly lower than that in the fixed exchange era.

Our results suggest that postwar stabilization policies have been successful in reducing real output volatility in Canada, Sweden and the United States. Our results are robust with respect to the methodology used. These results are different from those obtained by Romer $(1986,1989)$ and Bergman and Jonung (1993), implying that including the period of 1990s has a significant stabilizing effect resulting in reduced volatility estimates for the post-Bretton Woods era.

\section{SUGGESTIONS FOR FUTURE RESEARCH}

There are competing hypotheses about the causes of moderation in the business cycle behaviour during the post-Bretton Woods era. These hypotheses include the rise of the fiscal automatic stabilizers, financial reforms and private stabilization agents such as private pension plans. A natural extension of the present study is to examine the validity of these alternative hypotheses.

\section{REFERENCES}

1. Altman, M. (1992) Revised Real Canadian GNP Estimates and Canadian Economic Growth, Review of Income and Wealth, Series 38(4), pp.455-473.

2. Baxter, M. and R.G. King, (1995) Measuring Business Cycles: Approximate Band-Pass Filters for Economic Time Series, National Bureau of Economic Research, Working Paper Series, No. 5022.

3. Bergman, M. and L. Jonung, (1993) The Business Cycle Has Not Been Dampened: The Case of Sweden and the United States 1873-1988, Scandinavian Economic History Review, Vol. XLI, No. 1, pp. 18-36.

4. Canova, F. (1993), Detrending and Business Cycle Facts, Discussion Paper, No. 782, Centre for Economic Policy Research, London.

5. Gallman, R.E. (1966) Gross National Product in the United States, 1834-1909, in: Output, Employment and Productivity in the United States after 1800, Studies in Income and Wealth, Vol. 30, Conference on Research in Income and Wealth, New York: Columbia University Press (for NBER).

6. Hodrick, R.J. and E.C. Prescott, (1997) Postwar US Business Cycles: An Empirical Investigation, Journal of Money, Credit and Banking, Vol. 29, No. 1, pp.1-16.

7. Kendrick,J.W. (1961) Productivity in the United States, General Series, No. 71, Princton, N.J.: Princton University Press (for NBER). 
8. Nelson, C.R. and H. Kang, (1981) Spurious Periodicity in Inappropriate Detrending Time Series, Econometrica, 49(3), pp.741-751.

9. Newey, W. and K. West, (1997) A Simple, Positive Semi-Definite Heteroskedasticity and Autocorrelation Consistent Covariance matrix, Econometrica, Vol. 55, pp. 703-708.

10. Romer, C.D. (1986) Is Stabilization of the Postwar Economy a Figment of the Data? The American Economic Review, Vol. 76, No. 3, pp.315-334.

11. Romer, C.D. (1989) The Prewar Business Cycle Reconsidered: New Estimates of Gross National Product, 1869-1908, Journal of Political Economy, Vol. 97, No.1, pp. 1-37.

12. Romer, C.D. (1991) The Cyclical Behavior of Individual Production Series, 1884-1984, The Quarterly Journal of Economics, Vol. CVI, No. 1, pp.1-31.

13. Sheffrin, S.M. (1988) Have Economic Fluctuations been Fampened? A Look at Evidence Outside the United States, Journal of Monetary Economics, Vol. 21, pp.73-83.

14. Urquhart, M.C. (1986) New Estimates of GNP, Canada, 1870-1926: Some Implications for Canadian Development, in S. Engerman and R. Gallman, Eds., Long Term Factors in American Economic Growth, Chicago: University of Chicago Press, pp. 9-94.

15. Zarnowitz, V. (1992) Business Cycles: Theory, History, Indicators and Forecasting, Chicago: University of Chicago Press.

\section{NOTES}


NOTES 